\title{
WHY NGOs MATTER FOR THE SUCCESS OF SPORTS EVENTS: THE CASE OF THE AMERICA'S CUP
}

\author{
Tanguy Jacopin \\ Ignacio Urrutia
}




\title{
WHY NGOs MATTER FOR THE SUCCESS OF SPORTS EVENTS: THE CASE OF THE AMERICA'S CUP
}

\author{
Tanguy Jacopin* \\ Ignacio Urrutia**
}

\begin{abstract}
Collaborations between companies and NGOs have been widely described in literature. Little has been said, however, on how NGOs can become a key success factor for sporting events. To reduce the uncertainties linked with consumer responses, the assumption taken in this paper is that the study of behavior of the so-called "NGO activist" has become a better indicator than consumer responses in gauging the success of sporting events.

The illustration of the America's Cup provides an alternative framework to show how collaboration with the NGOs can create value for all stakeholders of the sporting event, and can even determine the evolution of the sporting event.
\end{abstract}

* Research Associate, IESE

** Professor of Accounting and Control, IESE

Keywords: stakeholder management, value creation, sport marketing, NGOs, sport events, America's Cup. 


\section{WHY NGOs MATTER FOR THE SUCCESS OF SPORTS EVENTS: THE CASE OF THE AMERICA'S CUP'}

"Activist NGOs are the shock troops of the Civil Society."

Sustainability, UNEP and Global Compact, 2003

Much of the literature about Corporate Social Responsibility ("CSR") and sporting events is suffused with Cause-Related Marketing ("CRM"). Little has been done, however, to foster CSR in terms of stakeholder analysis. The aim of this paper is to think about the benefits of considering Non-Governmental Organizations ("NGOs") as key drivers in the success of not only the sporting event but also the success of the other stakeholders in the 'orbit' of that event - these stakeholders may include citizens, the city, the sponsors, and even other related sport events. In short, our aim is to show that the benefits stemming from a connection to the NGO's behaviors are also conferred upon the sporting event and all its stakeholders.

The insights provided by NGOs' collaboration with companies have been widely described in literature (Drumwright, 1994, 1996; Waddock and Smith, 2000; Austin, 2000). However, there were no studies concerning the NGO's impact on sporting events.

This paper is based on two main assumptions:

1. As sporting events are becoming more and more professional, they can be compared to companies. Therefore, collaboration with NGOs has to be encouraged.

2. Consumers can no longer be considered as the most relevant key actor for companies and sporting events because they are re-active to change, whereas the necessity to create or capture value forces sporting events to look for pro-active partners. Besides, the emergence of "Civil Society Governance" is based on social, environmental and ethical criteria. In both cases, NGOs are more relevant partners than consumers.

From these two assumptions, we can deduce that the new key figures of the upcoming governance are those NGO members that will be called "NGO activists" in the rest of the paper.

\footnotetext{
${ }^{1}$ Instituto Noós financed part of the study.
} 
Indeed, it is the pro-active nature of the NGO activists combined with more sporadic dynamism from NGO supporters which justify this major change.

The case of Shell and Greenpeace in the North Sea in 1995 is paradigmatic of this new situation. Indeed, the behavior of the NGO activists sets in relief the importance of environmental criteria for oil companies far ahead of the market, and brought this to the attention of the consumers and oil companies. Such a change means that the activists do not exclusively represent a threat of attack against a sporting event but can also constitute an intangible asset if a business niche is associated with an emerging need. Therefore, the planning of sporting events should consider the incorporation of NGOs in order to increase their chances of success.

The $32^{\text {nd }}$ America's Cup in Valencia (Spain) will be used to consider the advantages of incorporating NGOs into the management of a sporting event. We will look at its success due to the major financial knock-on effect of the sporting event, and at its lack of cooperation until now with the NGOs. This is in contrast to the management of two other major sporting events, namely the Olympic Games and the Soccer World Cup, which did consider and act upon issues of CSR and sustainability. The possibility of highlighting some benefits to the major promoters and stakeholders of the regatta will open new perspectives in the collaboration among NGOs and sporting events.

\section{Hypotheses}

To minimize the uncertainties often linked to consumer responses, the assumption taken in this paper is that the NGO activists' behavior has become a better indicator (than consumer response) of the success or failure of sporting events, and can help to forecast the future evolution of those events.

The lack of insights provided by consumer responses in favour of sporting event development, coupled with the rising influence of stakeholders - among them, the NGO activists - make necessary to develop a theory based on the study of activist behavior (see Jacopin and Fontrodona, 2007, forthcoming).

Such a theory is necessary for the following reasons. First, their hypothetical actions against the sporting events have to be contemplated to find remedies. Second, the sporting events need to create methodologies to find reliable partners among NGOs. Third, thanks to their predictive perspective, NGO activists are the strategic link that enables the formation of a profitable customer base.

In the first part, the focus will be on the lack of insights provided by consumer responses to guide sporting events ever closer to their customers. This is the reason why the establishment of an alternative model based on the Civil Society and the different stakeholders is mandatory to unite (at best) sporting events with consumers and citizens. The third part will focus on the specific case of the America's Cup presenting the mapping of the selected NGOs first and then analysing the consequences of the prescriptions provided by NGOs. 


\section{Methodology}

As it is an exploratory survey, a low number of cases will provide sufficient insights to spur future projects. Our selection of NGOs has been according to their field of expertise, and in four different areas (environment, sport, development and Valencia NGOs). The decision to prioritize these areas can be justified by their direct relationships with this specific sporting event as well as their main relevancy among NGOs.

In-depth interviews with qualitative questionnaires were undertaken, while taking into consideration the fact that, in many NGOs, a very small number of people are involved in decision-making. Greenpeace, WWF/Adena, Intermón - Oxfam, Red Deporte y Cooperación, Deportes sin Fronteras, Dona Lliure, Societat Valenciana de Ornitologia and CIDEAL took part in this exploratory survey, with $42 \%$ positive answers. ${ }^{2}$

\section{Theoretical Framework}

Consumer responses constitute an essential area of study for marketers. Nevertheless, the insights provided by consumers are not as valuable as they should be in the context of generic and sporting literature. An additional problem arises from the governance shift towards "Civil Society Governance" that forces marketers to contemplate the replacement of the consumer by the NGO Activist as being the most important figure in a sporting event.

"Although a handful of studies have investigated the effects of various associations on consumer responses, their results are equivocal (e.g. Bolger, 1959; Clevenger, Hazier and Clark, 1965; Cohen, 1967; Hill, 1962). The inconsistent results leave marketing managers with the intuitive implication that a good image is probably better than a bad image (Brown and Dacin, 1997)". The impact of consumer response has remained unclear - for instance, some researchers such as Belch and Belch (1987), Wansik (1987) and Keller and Aaker (1994) found a positive correlation between positive corporate image and consumer response; Goldberg and Hartwick (1990) found correlation between consumer response and advertiser reputation, and Keller and Aaker (1992) found correlation between consumer response and corporate credibility. On the other hand, Shrimp and Beaden (1982) did not find any strong correlation between the reputation of the company and the consumer response. On their side, Brown and Dacin (1997) considered as well that the perceived differences in consumer responses were justified by the fact that "not all corporate associations are alike".

More specifically, the study of the correlation between consumer responses and sporting events provides the same uncertainties. Correlation with things such as sponsor recognition, image transfer from event to brand and favourable attitudes towards a sponsor were developed by Gwinner and Eaton (1999), Johar and Pham (1999), Pham and Johar (2001), Speed and Thompson (2000), and Roy and Graeff (2003), yet the latter study found that brand is only moderately related to brand/event fit.

Moreover, there is a problem that has not yet been dealt with - specifically, when the target audience of an event is a very small sample of the general public, then the wider general public

\footnotetext{
${ }^{2}$ Local associations in Valencia (from El Carmen, El Cabanyal and El Campanar) were also to take part in this survey, but so far it has been impossible to get any feedback from them. Two more NGOs promised to answer the survey... we shall see.
} 
can feel alienated by the perceived importance of that event in which they have no interest. In that case, to avoid potential conflicts arising with other stakeholders, the core target audience should no longer be the priority of the sporting event organisers. A multi-stakeholder dialogue approach should be developed to optimise the success of the sport event.

\section{Figure 1}

The New Framework under the Civil Society Governance

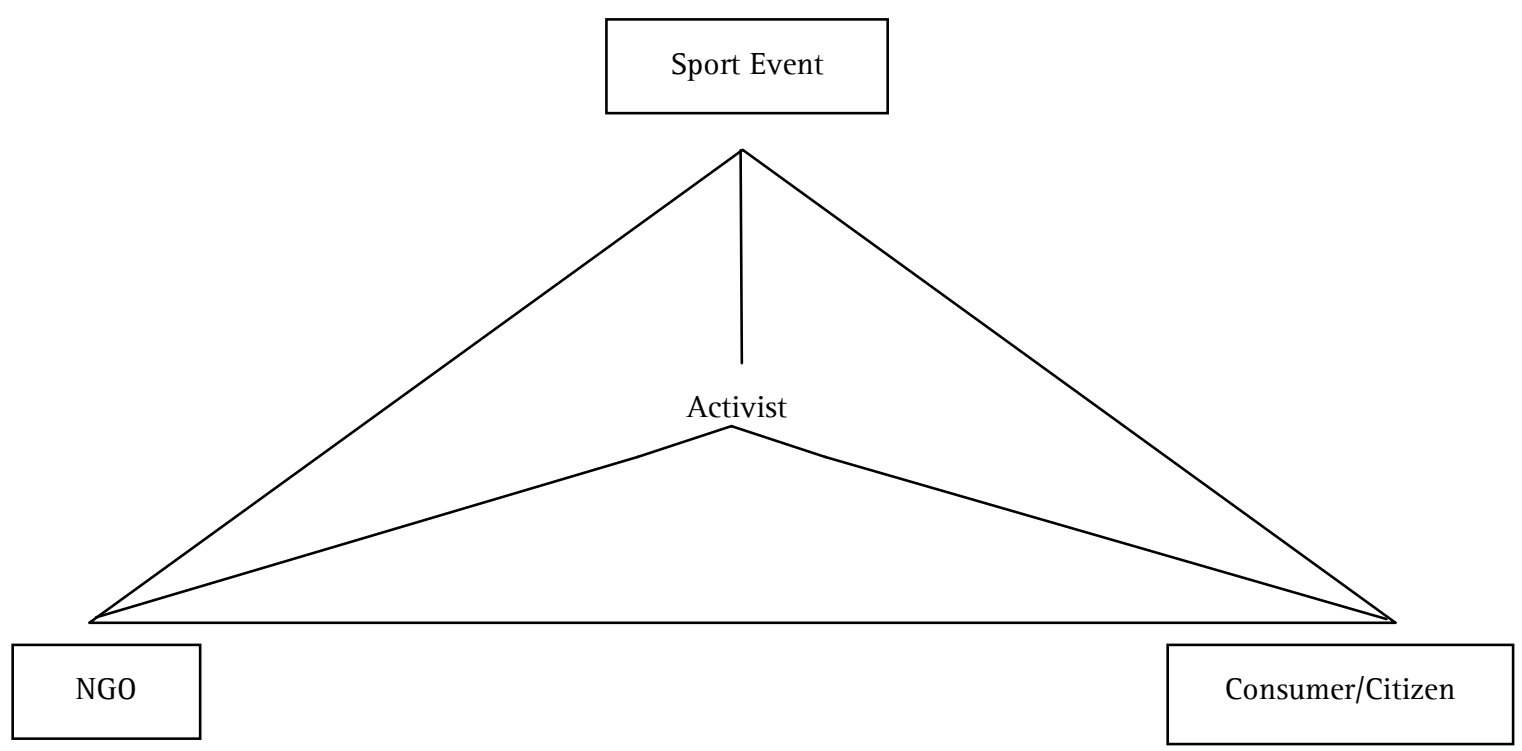

Source: Adaptation to Sport Event, from Jacopin and Fontrodona, (2007, forthcoming).

In that sense, the trend towards a new governance - what we call Civil Society Governance, in reference to the stakeholders - supposes the rise of a governance based on financial, environmental, ethical and social criteria, and one that is more complex than the previous, mainly finance-driven Corporate Governance. In that new arena, the NGOs are facing a new role and their exponential growth has brought them recognition from companies and nations. This context can provide sources of competitive advantage for the first companies that collaborate with NGOs. The same can be said for sporting events, the earlier they get involved with NGOs, the sooner they will be able to reach new target groups, ahead of their competitors.

Despite this, many companies and sporting events have been reluctant until now to contemplate the benefits of incorporating NGOs into their stakeholders, mainly due to their different opinion about the activists' increasing tendency to advocacy ${ }^{3}$ and eventual boycotts.

The awareness concerning the stakeholder issue has continuously increased in sport literature (Mason, Thibault, and Misener, 2006; Wenner, 2006; Mahony, Hums and Riemer, 2005; Mason

\footnotetext{
${ }^{3}$ The current NGO range of activities includes the "outreach, direct lobbying, education and research they undertake to raise awareness and contribution to public dialogue on issues at stake on any given relief" (Kappaz, 2001). Their transition from service delivery to this new mission was developed to justify their funding with respect to their own stakeholders and to be able to cope with the increasing levels of competition among NGOs.
} 
and Slack, 2001; Trail and Chelladurai, 2000). Nevertheless, the benefits and obstacles that NGOs can bring to sporting events have not yet been studied.

In that sense, concerning obstacles, if the organization of the boycott has corresponded far more to political and company issues, the 'professionalisation' of sporting events changes the way sporting events can be perceived. Therefore, sporting events can become victims of boycott as well if they do not take sufficient care of their different stakeholders and, among them, the NGOs. Events such as the boycott of Areva for the $31^{\text {st }}$ America's Cup by Greenpeace activists in 2001 are likely to occur much more frequently. The segmentation and consideration of NGOs are therefore key issues for sporting events if they want to avoid boycotts or, at least, not to be seen as remote from the preoccupations of their customers or, more broadly, the general public. As a boycott's effectiveness is high in the short term and then decreases over time (Friedman, 2002), and as the main change in boycott organizations has been the fact that NGOs and activists are now typically the catalysts of the frustration or claim of consumers and citizens, the interest to study the activist, rather than the consumer, is completely justified.

The shift towards Civil Society Governance has favoured a better acceptance of NGOs. Thus, the dialogue with NGOs can be contemplated more easily because of the potential for competitive advantage resulting from collaboration with NGOs. Therefore, sporting events require a new approach when considering their stakeholders. This study deals specifically on how the sporting event organizers can improve their knowledge of the NGOs involved in their field.

\section{The America's Cup}

The America's Cup is the oldest sporting event in the world, and undoubtedly the most prestigious trophy to be won in sailing. The first event took place in 1851 around the Isle of Wight, in England. The America, a racing vessel from New York, won the competition and gave its name to the competition previously called "The 100 Guinea Cup". The winner received the "Deed of Gift", which declared that any sailing club from anywhere in the world could challenge the winner of what was now called "The America's Cup".

The New York Yacht Club managed to keep the trophy for 132 years and 25 challenges, a unique phenomenon of superiority in sporting history. Nevertheless, in 1983, an Australian vessel achieved the impossible and, due to the ancestral rules bound with this trophy, the 100 Guinea Cup moved to the southern hemisphere for 4 years before returning to the US after another American victory. The superiority of the American sailors did not last long, though, as the Cup headed back to the southern hemisphere again 4 years later and remained for 8 years in New Zealand till Alinghi, the Swiss team, won the Deed of Gift.

This meant that Alinghi and Switzerland had to organize the following America's Cup but, as every schoolboy knows, Switzerland has no sea coast. Therefore, a competition among 60 cities was organized to establish the location of the $32^{\text {nd }}$ America's Cup, with Valencia eventually winning the privilege to host this most prestigious sailing event.

Winning the right to host the America's Cup is not the same as winning the competition itself, and may be considered a far greater challenge. Indeed, the economic impact of hosting an event lasting from October 2004 till July 2007 is enormous, particularly the impact on the construction and tourism industries. To this end, KPMG (2004) undertook a study which estimated that the growth impact on the Community of Valencia would be around $1.7 \%$ versus $1.1 \%$ for the 
previous edition of the America's Cup. Moreover, it would generate $€ 3,150$ million in production, taking into account the direct and indirect effects, and would create some 27,760 jobs during the whole duration of the competition, with some $70 \%$ of the profits remaining in the Community of Valencia.

Nevertheless, KPMG (2004) pointed out "the considerable (lack of) awareness of the actual indicators and development projects generated by the America's Cup, which leads to a low preparation level in the business community of Valencia". Informing target audiences of the benefits of sponsorship could have helped develop the mental associations bound with the sponsor or the event.

Moreover, there is that other problem that has not yet been dealt with - that of the target audience being very small compared with the general public, and thereby the general public can feel alienated by the perceived importance attached to the event. Being a high-profile media event (and being seen as somewhat elitist), the America's Cup can be considered a likely case where the effective target groups have been reached successfully but where the general public has been kept apart from the sporting event (or at least feels distanced), despite the public's enthusiasm or willingness to be involved (Factiva, 2005).

That "lack of awareness" highlighted by KPMS has progressively decreased in the population of Valencia (Instituto Noós, 2006), and, as a result, the collaboration between the America's Cup management and the public authorities of Valencia (united behind the "Consorcio Valencia") have succeeded in designing new processes to create value for their main targets, namely the media, sponsors and sailing teams. The America's Cup management had ample opportunity for creating value by increasing the number of tournaments before the final, thereby increasing the exposure of their own sponsors, and that of the generic sponsors of the event, through the resulting increased impact in the media.

In that sense, the current paper acknowledges the general public's lack of interest or lack of opportunity for involvement by considering the NGO activists as the most likely to increase the chances of the Valencian people's involvement in the America's Cup.

\section{NGO Mapping}

In order to use a multi-stakeholder approach, this study realized a mapping of NGOs bound with the America's Cup. Greenpeace, WWF/Adena, Intermón - Oxfam, Red Deporte y Cooperación, Deportes sin Fronteras, Dona Lliure, Societat Valenciana de Ornitologia and CIDEAL were the eight NGOs interviewed and dispatched according to their status be they environmental, developmental, sport or Valencia NGOs. The results of this qualitative survey are presented first, NGO by NGO. Later, we present a new global framework to improve communication with the America's Cup as well to foster change.

The beneficial impact of the America's Cup on the Valencia Community has until now been considered by all NGOs to be minimal, whether for the general public, for the environment, for the real estate sector, or even for the sporting event itself. Nevertheless, all the NGOs are willing to get involved with the America's Cup to help things change, and they all consider that they share the same values as found in sailing, such as team spirit, solidarity, sharing. Nevertheless, it has to be noted that only two NGOs, Intermón-Oxfam and Red Deporte y Cooperación, have effectively tried to get in touch with the sporting event organization or sailing teams. 
Red Deporte y Cooperación announced their intention to lead a project from October 2005 with the South African team.

Thus, the organization and the sailing teams have the opportunity to influence the NGOs and to try to foster a new dynamic that will help to satisfy all the stake-holders and feed back the perception and the psychological associations of the America's Cup. Such a move would be as relevant as the International Olympic Committee's (IOC) decision to involve NGOs in setting standards for the Olympic Games. 

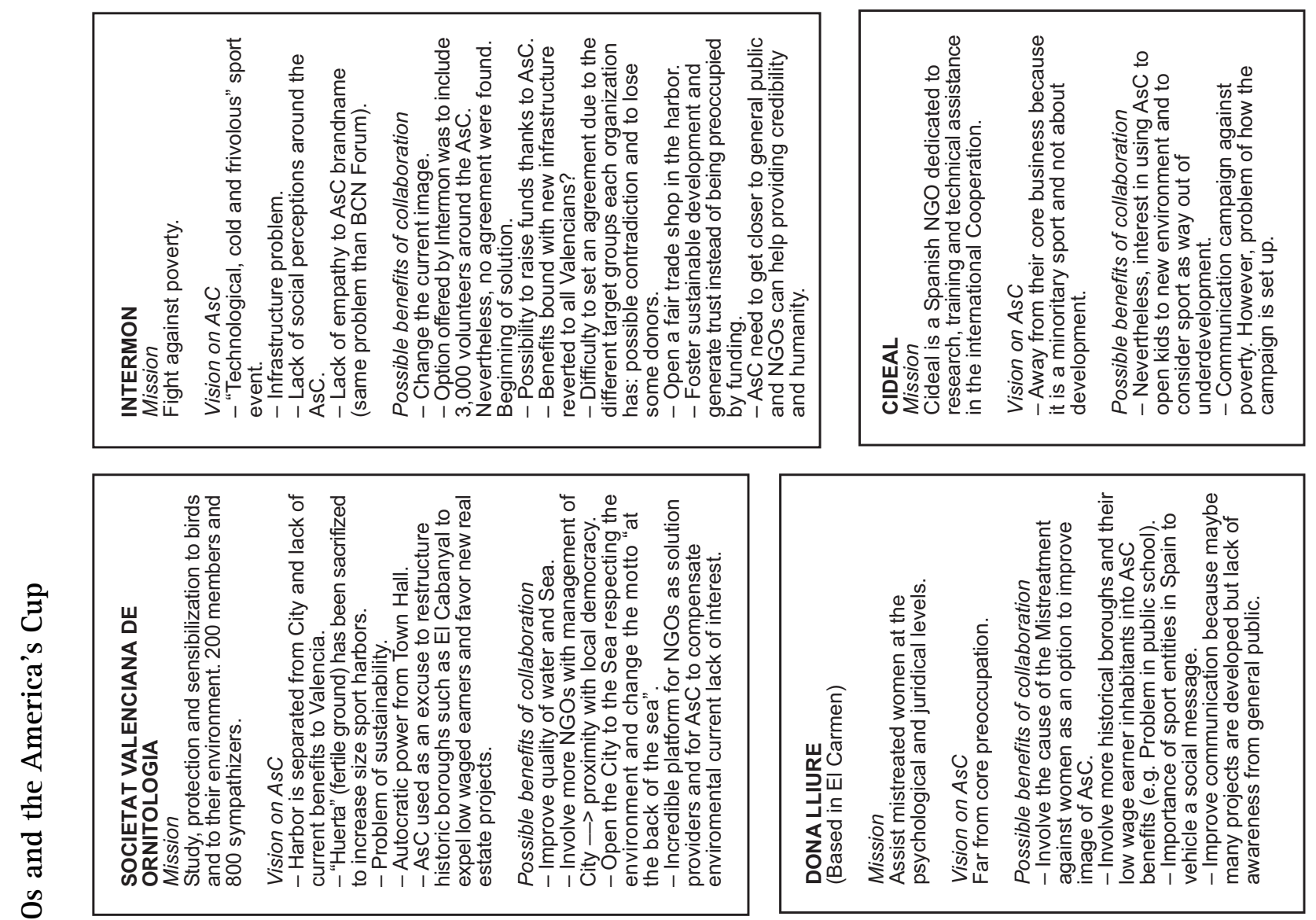

告
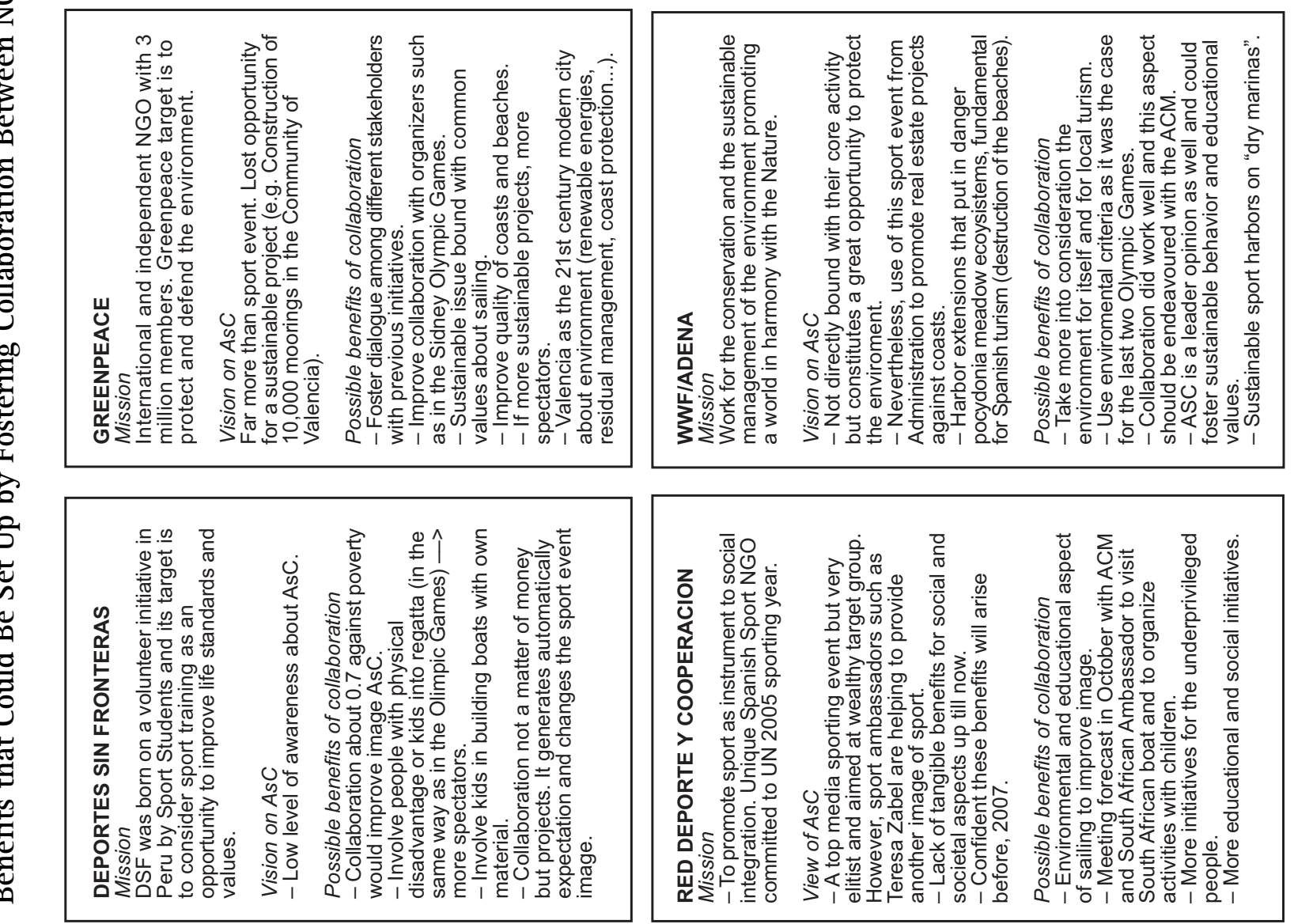

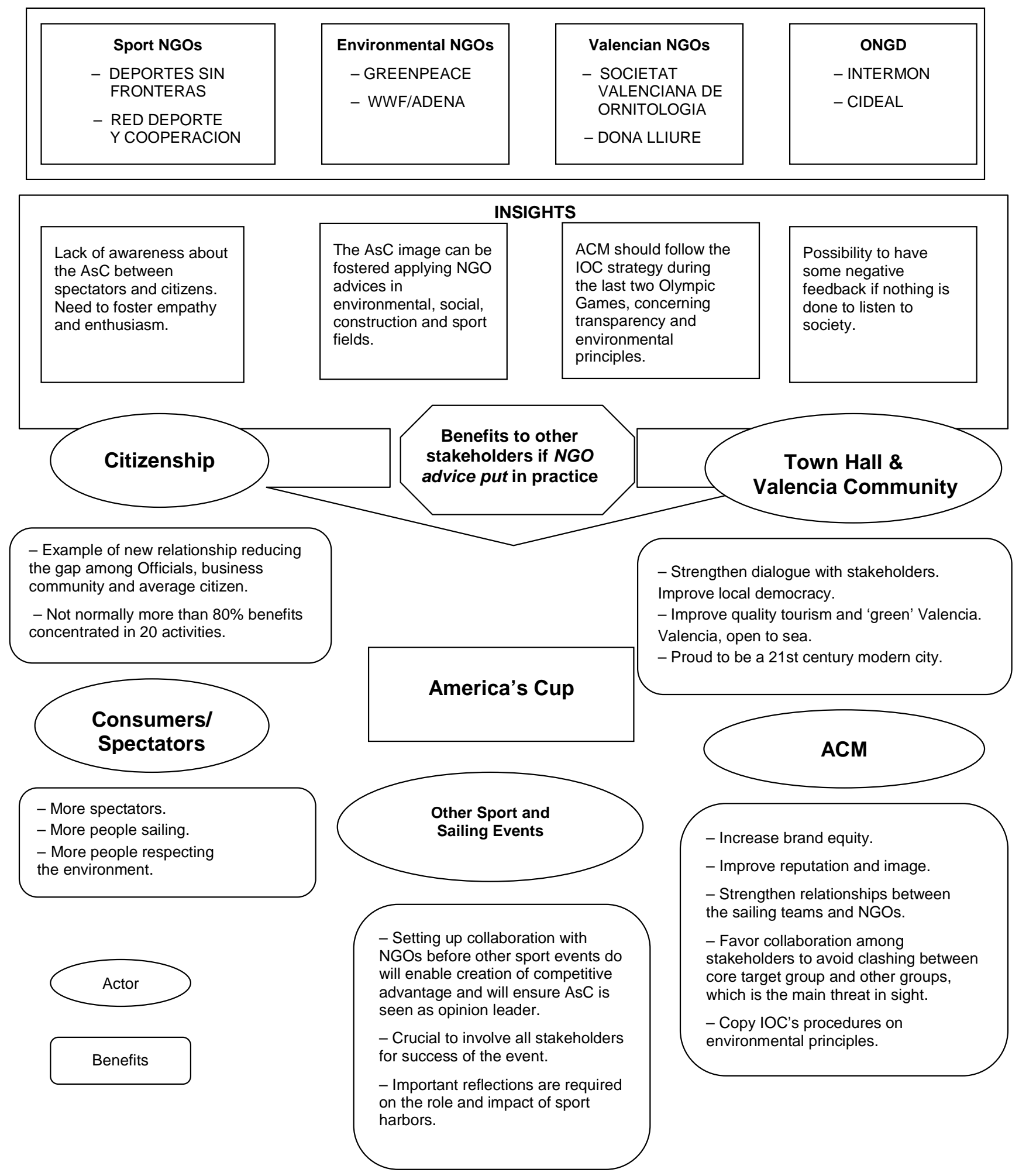


\section{Conclusions}

Instead of trying to foster consumer response insights from another perspective, this contribution decided to take into consideration the shift towards the Civil Society Governance where the NGO Activist constitutes the main emerging stakeholder for the companies. This work was based on the assumption that sporting events should be likened to companies. Therefore, sporting events "have to let NGOs be and act as NGOs" Simmons (1998) because that is the only way to reach the "critical cooperation" Covey and Brown (2001), defined as "the possibility to manage not just cooperation or conflict but cooperation and conflict in the same relationship".

Future contributions should increase the size of the sample and evaluate to what extent the tools of consumer behavior theory can apply to activist behavior theory. Specific tools for the theory of activist behavior will have to be developed in the future to ensure that the CR practices are improved.

The main goal of this paper was to provide a new framework that favors the closing of the gap existing between NGOs and sporting events such as the America's Cup. The current situation of mutual ignorance could easily be changed, thanks to the common values shared by sporting events and NGOs. Moreover the current climate of willingness to find ways of improving consumer perceptions about the America's Cup should open new perspectives to this top class event.

Interviews conducted in NGOs

\begin{tabular}{|l|l|l|}
\hline & People & Function \\
\hline INTERMON & Mr. Raventós & Marketing Area \\
\hline CIDEAL & Mr. Gómez & President \\
\hline Deportes sin Fronteras & Ms. Fírvida & President \\
\hline Red Deporte y Cooperación & Mr. Dalury & Institutional Relations \\
\hline GREENPEACE & Ms. Caballeros & Coast Area \\
\hline WWF/ADENA & Mr. García & Coast Area \\
\hline Societat Valenciana de Ornitologia & Mr. Peris & President \\
\hline Dona Lliure & Mr. Xavier & Psychologist \\
\hline
\end{tabular}




\section{References}

Austin, J. (2000), "The Collaboration challenge. How non-profits and businesses succeed through strategic alliances," Jossey Bass Publishers.

Creyer, E. and W. Ross (1997), "The influence of firm behavior on purchase intention: do consumers really care about business ethics?" Journal of consumer marketing, vol. 14, No. 6.

Drumwright, M. (1996), "Company Advertising with a Social Dimension; the Role of Noneconomic Criteria,” Journal of Marketing, 60, pages 71-87.

Drumwright, M. and P. Murphy (2001), "Corporate Societal Marketing," in Bloom P. and G. Gundlach (eds.) "Handbook of Marketing and Society," Sage Publications, Thousand Oaks, CA, pages 162-183.

KPMG (2004), “America's Cup 2007: Economic impact and expectations of the business community in Valencia.

Mahony, D., M. Hums, and H. Riemer (2005), "Bases for Determining need: Perspectives of intercollegiate Athletic Directors and Athletic Board Chairs," Journal of Sport Management, vol. 19, (2), April.

Mason, D., L. Thibault, and L. Misener (2006), “An Agency Theory Perspective on Corruption: The Case of the International Olympic Committee," Journal of Sport Management, vol. 20, (1), January.

Nieto, L. (coord.) (2002), “La ética de las ONGD y la lógica mercantil,” Icaria.

Roy, D. and T. Graeff (2003), "Influences on Consumer Responses to Winter Olympics Sponsorship," International Journal of Sport Marketing, December-January.

Schwartz, P. and G. Blair (1999), "When good companies do bad things," Library of the Congress.

Sen, S. and C. B. Bhattacharya (2001), "Does Doing Good Always Lead to Doing Better? Consumer Reactions to Corporate Social Responsibility," Journal of Marketing Research, 38, pages 225-243.

Simmons, P. J. (1998), “Learning to live with NGOs, Foreign Policy, Fall.

Waddock, S. and N. Smith (2000), "Corporate Social Responsibility audits: doing well be doing good," Sloan Management Review, 41, (2), pages 75-83.

Wenner, L. (2004), “Introduction: Recovering (from) Janer Jackson's Breast: Ethics and the Nexus of Media, Sports and Management," Journal of Sport Management, 18, (4), October. 